\title{
Investigating Contact-induced Change in Heritage Turkish: A Study on the Use of Temporal -DIK Converbial Constructions
} Miras Dil Olarak Türkçede Değinim-Kaynaklı Değișimi İnceleme: Zaman Ulacı -DIK'ın Kullanımı Üzerine Bir Çalışma ${ }^{1}$

\author{
Mehmet Akkuş \\ Artvin Çoruh University, Turkey \\ Çiğdem Sağın Şimşek \\ Middle East Technical University, Turkey \\ Albert M. Backus \\ Tilburg University, the Netherlands
}

\begin{abstract}
This study presents an analysis of a contact-induced language change process concerning temporal -DIK converbial constructions in the variety of Turkish spoken in the Netherlands (henceforth, Dutch Turkish). This study particularly aims to investigate whether these converbial constructions are prone to language change in the speech production of the first and second generations of Dutch-Turkish speakers within the framework of usage-based linguistics. In line with the research aims, this study utilizes semi-structured interviews applied to three groups of participants: Dutch-Turkish bilingual speakers from a first-generation background $(n=11)$, DutchTurkish bilingual speakers from a second-generation background $(n=12)$ and a control group of Turkish monolingual speakers $(n=12)$. Analyses of the data obtained from the three groups of participants reveal that the participants' speech production of converbial constructions indicates a linguistic change in converbial constructions in the frequency of the use of converbs.
\end{abstract}

Keywords: contact-induced change, temporal converbial construction, Turkish, Hollandaca, $-D I K$

Öz

$\mathrm{Bu}$ çalışma Hollanda'da yaşayan Türkçe-Hollandaca iki dilli bireyler tarafından konuşulan Türkçe değişkesinde kullanılan zaman ulacı -DIK yapısını incelemektedir. $\mathrm{Bu}$ çalışma kapsamında Hollandaca-Türkçe iki dilli bireylerin kullandığı Türkçede zaman ulaç eki -DIK yapıları incelenmekte ve bu iki dilli ortamda söz konusu Türkçe ulaç yapısının, Hollandacanın etkisiyle, dilbilgisel bir değişim içinde olup olmadığı kullanım tabanlı dilbilim kuramı çerçevesinde sorgulanmaktadır. Bu araştırma amaçları için Hollandaca-Türkçe iki dilli ve Türkçe tek dilli katılımcılardan yarıyapılandırılmış görüşmeler aracılığıyla veri toplanmıştır. Üç farklı katılımcı grubundan veri toplanmıştır. Grup 1'de yer alan 11 katılımcı Hollanda'ya çalışmak amaçlı giden birinci nesil Hollandaca-Türkçe iki dilli bireylerden oluşurken Grup 2'deki katılımcılar Hollanda'da doğup büyüyen ve ikinci nesil içerisinde değerlendiren 12 iki dilliden

\footnotetext{
1 We would like to thank the anonymous reviewers for their valuable feedback. This article is based on the data obtained for the PhD dissertation "A usage-based investigation of converbial constructions in heritage speakers' Turkish living in the Netherlands" (Akkuş 2019).
}

CUJHSS, December 2021; 15/2: 223-241.

(C) Çankaya University ISSN 1309-6761 Printed in Ankara

Submitted: August 14, 2021; Accepted: September 20, 2021

ORCID\#: 0000-0002-9604-1418; 0000-0002-5234-7546; 0000-0001-8596-8915

mehmetakkus@artvin.edu.tr 
oluşmaktadır. Hollanda'da toplanan verinin karşılaştırılması amacıyla Türkiye'de katılımcların göç ettikleri illerdeki 11 tek dilli Türkçe konuşurundan da veri toplanmıştır. Çalışmada kullanılan veriler; ulaç kullanım biçimleri bağlamında inceleneceğinden öncelikle beş Türkçe-Hollandaca iki dilli ve beş Türkçe tek dilli katılımcının günlük yaşamları içerisinde, farklı dilsel bağlamlarda, kullandıkları sözlü iletişimleri ses-kaydı yapılarak toplanmıştır. Elde edilen bulgular neticesinde Hollanda'da yaşayan Hollandaca-Türkçe iki dilli bireylerin kullanım bağlamında ulaçlı yapıların Türkçe tek dilli katılımcılara göre daha az kullandıkları ve kullanım türleri bağlamında ise devam eden değinim-odaklı bir değişimin var olduğu ortaya çıkmıştır. Anahtar Kelimeler: değinim-kaynaklı değişim, zaman ulaç yapısı, Türkçe, Hollandaca, $-D I K$

\section{Introduction}

Language contact is undeniably a fact of the globalized world due to the growing possibilities of mobilization of diverse language speaking communities led by migration, expanding global trade, and recent developments in communication technologies. Thus, diverse language speaking communities and their respective languages regularly come into contact. Several researchers have reported that in language contact situations, it is possible to expect contact induced language changes (Weinreich 7; Thomason and Kaufman 14; Thomason 12; Johanson 10; Heine and Kuteva 3; Winford 5). Contact-induced change may manifest itself either unidirectionally in contexts where one language is asymmetrically dominant over a second language or bidirectionally in balanced bilingual contexts. As one would expect, in addition to the nature of the linguistic context, numerous other linguistic and socio-political factors, such as the duration and the intensity of the contact, language typologies, language status and the attitudes of the speakers' have an influence on the manifestations of contactinduced change (Myers-Scotton 17; Matras 34; Winford 7). While some scholars suggest that lexical items are more vulnerable to change (Haugen 4; Johanson 8), others suggest that structural changes are more likely to occur as an outcome of long-term, intensive language contact (Weinreich, 44; Sankoff and Poplack 78; Thomason and Kaufman 57). Nevertheless, "languages can influence one another in a situation of contact but predicting the outcome of a language contact situation remains an immensely challenging task" (Siemund 3). This challenge has led many scholars to investigate which domains are more vulnerable to contact-induced language change. A review of literature on this issue reveals that no consensus has been reached yet. On the one hand, syntax is suggested to be highly vulnerable in language contact situations (Heine and Kuteva 18). On the other hand, Silva-Corvalán perceives language change as a process of simplification that starts with morphology, continues in the lexicon and only influences the syntax later on (255). Researchers have concluded that 'any linguistic feature can be transferred from any language to any other language given the right mix of social and linguistic circumstances' (Thomason and Kaufman 59) but "no aspect of language change is completely predictable" (Doğruöz and Backus 191). Even though there are various borrowing scales proposed to rate the vulnerability of each domain (Thomason and Kaufman 68; 
Matras 113), inconsistencies in reported research show us the need to further examine the factors that facilitate or hinder contact-induced change.

Another issue that has yet to be resolved concerns the extent of conventionalization that a linguistic element undergoes in language contact situations. It is not always straightforward to disentangle whether an unconventional pattern of language use represents a unique instance or whether it is conventionalized by most members of the speech community. Hence, recent studies have employed usage-based linguistics as a framework to measure the degree of conventionalization (Backus 770). Usage-based linguistics concentrates on the impact of usage in language structure (Langacker 12) and sees an "intimate relation between linguistic structures and instances of use of language" (Barlow and Kemmer 2). Thus, the frequency of the use of linguistic elements is conceived as a fundamental factor in usage-based linguistics. (Barlow and Kemmer 15; Bybee 39). If a linguistic element or pattern is used frequently, it means the linguistic element is entrenched and cognitively routinized.

This study aims to contribute to the language contact literature by examining whether Turkish temporal -DIK converbial constructions are prone to contactinduced change in the heritage Turkish language spoken in the Netherlands within the framework of usage-based linguistics.

\section{Turkish as a heritage language in the Netherlands}

Several studies conducted in immigrant contexts label immigrant children as 'second-generation heritage speakers' and distinguish them from other bilingual speakers (Benmamoun, Montrul, and Polinsky 129; Dabrowska 195; Kupisch 203; Meisel 225; Muysken 237; Rothman and Treffers-Daller 93). Despite the debate regarding the characteristics of heritage language speakers, they are commonly described as "early simultaneous or early sequential bilinguals who are relatively unbalanced in their two languages, as they are dominant in their L2" (Van Rijswijk 19). One of the characteristics of heritage speakers is their inheritance of their first languages from their parents in spite of the fact that these speakers are "born and raised in a society in which a different language is the majority language" (Van Rijswijk 1). This majority language, which is their second language, becomes their dominant language. The contact of the heritage language with the dominant language is reported to cause unconventionalities in the speech of heritage speakers (Meir and Polinsky 222).

In the context of this study, the Netherlands, Dutch serves as the dominant language as it is spoken by the majority of speech communities, including native speakers of Dutch and many bilingual immigrant communities, one of which is the immigrant Dutch-Turkish bilingual community. Parallel with the economic growth of some other Western European countries like Germany, the Netherlands experienced a tremendous industrial growth that led to a need for more workers for their growing industries. Thus, the country started negotiations with Turkey to import labour force, and on 19 August 1964 the two countries signed a "recruitment agreement" to solve the labour shortage 
problem of the Netherlands. Since then, for the first and following generations (heritage language speakers), Turkish has become an immigrant minority language in the Netherlands for half a century now. According to the statistics provided by Statistics Netherlands (CBS), in total there are around 400.000 Turks living in the Netherlands. While around 190.000 of them are first generation speakers, the number of Turkish heritage speakers are around 213.000. Even though existing reports claim that there are relatively high language maintenance figures (Backus 772; Doğruöz and Backus 188; Extra, Yağmur and Van der Avoird 109), due to the status and language dominance asymmetry between Turkish and Dutch languages in the Netherlands, the community is under constant pressure to shift to Dutch (Doğruöz and Backus 41).

Turkish as a heritage language has attracted scholarly attention from a number of perspectives, ranging from pragmatic and sociolinguistic aspects of TurkishDutch bilingualism, such as language use and preference (Backus and Yağmur 817), and identity formation (Extra, Yağmur and Van der Avoird 109) to Turkish language education in Dutch schools (Akoğlu and Yağmur 706). Regarding the linguistic outcomes of the contact of Turkish and Dutch, there are studies focusing on Turkish-Dutch bilinguals' use of code-switching, insertions, and loan translations (Backus 23). The scope of this study is limited to the linguistic outcome of contact-induced change in heritage Turkish in the Dutch context. Since the focus of the study concerns temporal -DIK converbial constructions in Turkish, it is necessary to look at studies that have examined Turkish converbials in contexts of language contact.

As far as we know, in the Dutch context, converbs in heritage Turkish have only been studied by Onar Valk and Akkuş in their doctorate dissertations. Onar Valk investigated the Dutch-Turkish bilinguals' production of non-finite subordinate clauses as a part of her study and concluded that the adverbial clauses comprising converbs such as $-A r A k$ and $-I p$ are produced more often than the other adverbial types (156 et passim). The study reported that the reason behind the high frequency of -ArAk and -Ip may be based on the fact that these converbs are not inflected for tense, case or person. Thus, they are considered as being less complex or simpler (156 et passim). Akkuş studied whether or not the converbial constructions have been prone to language change in the speech perception and production of the first and second generations of Dutch-Turkish speakers within the framework of usage-based linguistics (3 et passim). Based on a grammaticality judgment task focusing on converbs -Ip, -IncA, -ken and $A r A k$ and natural production data obtained through interviews, the study reported conventional and unconventional use of converbial constructions in the heritage Turkish in the Dutch context. The study revealed that the participants' perceptions and speech production of converbial constructions indicate a linguistic change regarding frequency and pattern of use. Particularly, a gradual decrease in the frequency of converb use and unconventional usages of converbs in non-finite constructions are reported in the data collected from the second-generation speakers. 
The linguistic focus of this study, temporal -DIK converbial constructions in heritage Turkish, has been examined only by Herkenrath in the German context (219). The study utilized data obtained from Turkish-German bilingual children, Turkish monolingual children and adult speakers who were present during the conversations with the children. The study reported that the monolingual children growing up in Turkey employed more -DIK constructions than the bilingual children growing up in Germany. Additionally, -DIK constructions used by the bilingual children reflected a more restricted range of forms. The study reported the use of three aspectual converb types (-DIğIndA, -DIktAn sonra, and -DIğI zaman), one causal type (-DIğI için), one comparative type (-DIğI kadarlyla), and in one instance an equative construction (-DIkçA). The researcher stated that the bilingual children did not use a number of forms that were commonly used by the monolingual children.

Similarly, Rehbein and Herkenrath (493) examined the use of converbs -Ip, IncA, -ken, and -ArAk in heritage Turkish spoken by German-Turkish bilingual children. The researchers reported that the use of these converbs by the German-Turkish bilingual children contrasted with the way Turkish monolingual children used converbs. The study revealed that while the examined converbs seem to be invulnerable to contact-induced language, the bilingual data presented syntactic patterns that were unlike the patterns found in monolingual speech. In the same context, the perception and use of $-I P,-I n c A$ were examined by Turan et al. (1035). Based on a grammaticality judgement task and a picture-story description task utilized in the study, the study reported differences between the Turkish-German bilinguals and Turkish monolinguals in perception of the grammatical constructions with -IncA and of the ungrammatical constructions with $-I p$ and $-I n c A$. However, the study reported no significant difference in the perception of the grammatical constructions with -Ip. As for the production of the converbs, the bilingual participants used the converbs significantly less than the monolinguals.

\section{Converbial -DIK constructions in Turkish}

The term converb is defined as "a non-finite verb form, whose main function is to mark adverbial subordination" (Ramstedt 55). Converbs are regarded as verbal adverbs that function as clause linking devices that indicate clausal relations such as manner, sequence or condition. Haspelmath (3) describes converbs with reference to their specific syntactic, morphological, and semantic features and states that converbs are syntactically, subordinate, embedded as adverbial constituents; morphologically, nonfinite and semantically modifiers of verbs, clauses or sentences. Likewise, converbs in Turkish are non-finite, embedded verb forms that express time, manner, purpose and result, cause, condition, degree, place and concession.

One of the frequently used converbs in Turkish is -DIK and it is used for the realization of participles, verbal nouns, and also 'complex converbs'. The complexity of the -DIK converbial constructions, as explained in the following sections, is due to their occurrence in a range of combinations with possessive and case suffixes as well as postpositions (Herkenrath 222). In addition to their 
morpho-syntactic complexity, converbial -DIK constructions fall into a variety of semantic categories, including casual, equative, and temporal and hold semantic complexity as well. Since the scope of the present study is limited to the use of temporal $-D I K$ converbial constructions, the following sections include explanations regarding only temporal $-D I K$ converbial constructions.

In discourse, temporal $-D I K$-rooted converbial constructions mainly serve as connectors "in utterance-internal connectivity, serving a range of communicative functions in concatenating complex speech. One of the core functions of $-D I K$ consists in processing propositional knowledge and integrating it into larger interactional units" (Herkenrath 220). Together with case and possessive markers, and postpositions, -DIK-rooted converbial constructions specifically imply the following temporal relations with the main clauses:

(1)-DIK-Poss.-Case: -DIğIndA,

The event or action of converbial construction with -DIK-POSS.- noun: -DIğI zaman is connected to the main clause, implementing a parallelism and/or overlapping -and possibly a trace of anteriority- between the events.

(2) -DIK-Poss.-Case Pop: -DIktAn sonra,

The converbial construction in combination with -DIK-POSS.-CASE POP: -DIktAn sonra implements an anteriority relation between non-finite subordinate and finite main clauses.

(3) -DIK-Poss.-(Case)- noun-(Case): -DIğI zaman; -DIğI sürece; -DIğI an.

All events in -DIK-rooted aspecto-temporal converbial constructions follow the rules of simultaneity and/or overlapping of their representation within an utterance-internal connectivity in discourse.

\section{The Study}

This study aims to investigate whether the use of converbial constructions by the Turkish heritage speakers in the Netherlands is subject to contact-induced language change. Focusing on the temporal -DIK converbial constructions, the study explores whether the use of temporal -DIK converbial constructions reveals differences in terms of frequency and pattern by the first-generation Dutch-Turkish bilingual speakers, second generation Dutch-Turkish bilingual speakers and the Turkish monolingual.

\section{Participants}

In line with the aims of the study, the following three groups of participants are observed in the present study: first- and second-generation Dutch-Turkish bilingual speakers and Turkish monolingual speakers. The rationale behind including two generations of the Dutch-Turkish bilingual speakers in the study was based on the assumption that if the temporal-DIK converbial constructions are vulnerable to language contact in heritage speakers' speech, a divergence in their use of temporal -DIK converbial constructions would be expected in comparison with the monolingual Turkish speakers. Prior to data collection, a 
language background questionnaire was given to all of the participants in order to gain information about the languages they know and use in different social contexts, their language preferences and attitudes towards their languages.

\section{Second generation Dutch-Turkish bilingual participants}

Dutch-Turkish bilingual speakers with second generation background ( $\mathrm{n}=12)$, who are referred to as heritage speakers in this study, constitute the experimental group of the study. Based on the data obtained through the language background questionnaire, the second-generation bilingual DutchTurkish participants were between the ages of 18 and 29 and from a variety of cities in the Netherlands. They all considered themselves as Dutch and were graduates of a higher education program $(n=8)$ or a high school $(n=4)$. All twelve participants in this group acquired Turkish as their first language within their family environments but did not consider themselves "fully-competent" in Turkish. They reported difficulties in using Turkish in formal situations, such as, when reading a newspaper or filling in a form in Turkish. All family members had their origin and relatives in Turkey, even though they were all born and raised in the Netherlands. When they were asked where they were from, without exception, they all identified their origins with a Turkish city where their ancestors came from. Turkish was reported to be spoken as a family language among family members (overwhelmingly with grand parents), and with older, first-generation immigrants.

\section{First generation Dutch-Turkish bilingual participants}

The second participant group included in the study consisted of eleven first generation bilingual Dutch-Turkish speakers who migrated to the Netherlands, marrying a Netherlands-born Turkish partner. They acquired Turkish as their native language in Turkey and learned Dutch in the Netherlands upon their arrival. They did not consider themselves as fluent speakers of Dutch in contrast to their children and grandchildren. They reported frequent use of Turkish with their relatives and neighbors and occasional use of Dutch for their daily interactions with the Dutch community in official institutions, supermarkets, restaurants, etc. The participants reported their education background to be rather low. Only one participant graduated from high school and seven participants completed their primary and secondary education. Similar to the first group, face-to-face one-to-one and group interviews were held in natural contexts such as home visits, and meetings at dinner tables, in cafés etc. with the first-generation bilingual Dutch-Turkish speakers.

\section{Turkish monolingual participants}

The last group, the control group, consisted of twelve Turkish monolinguals. The data gathered from the non-contact language variety, language produced by Turkish monolingual speakers in this study, plays a crucial role in assessing the extent of contact. The monolingual participants were selected through snowball sampling. Both the second- and first-generation Dutch-Turkish bilingual participants were asked to contact their monolingual relatives living in Turkey to participate in the study. Among those who accepted to take part in the study, 
twelve monolinguals whose age, regional and educational background were similar to the heritage speakers in the Netherlands were invited to the study. The Turkish monolingual participants' ages ranged from 19 to 30. As for their educational background, six of them were high school graduates, whereas the other half either graduated from a high school or were continuing their education during the time of the interviews. They all evaluated themselves as native speakers of Turkish and beginner level learners of English. Lastly, the socio-economic backgrounds of the participants were quite similar to one another.

\section{Data Collection Instruments}

The data for the study were collected through spontaneous one-to-one and inter-group interviews triggered by questions formulated within semistructured interviews conducted in natural language use environments. In order to obtain information about the participants' background, a language background questionnaire was also given to the participants.

\section{Language Background Questionnaire}

The language background questionnaire consisted of four sections. The first section aimed to identify the languages known by the participants and their family members. The second section asked questions about the order, age and setting of language acquisition. The third section asked the participants to selfevaluate their proficiency levels in both perception and production competencies in the languages that they know. The last section aimed to reveal language use and choice patterns in communicating with their parents, relatives, friends, neighbours and classmates in a variety of given social settings.

\section{Interviews}

This study makes use of a corpus consisting of spontaneous natural interviews as the main qualitative data collection tool. Having received the consent of the participants, spontaneous (and semi-structured) one-to-one and inter-group conversational interviews were conducted. All the interviews were audiorecorded. Descriptive information of all interviews that form the corpus of the study are presented in Table 1.

Table 1

The Corpus of the Study

\begin{tabular}{lllll}
\hline Corpus & $\begin{array}{l}\text { Interview } \\
\text { type }\end{array}$ & $\begin{array}{l}\text { Participants } \\
(\mathbf{N})\end{array}$ & Duration & Utterances (N) \\
\hline $\begin{array}{l}\text { 2nd Gen D-T } \\
\text { Bilin. }\end{array}$ & One-to-one & 3 & $3 \mathrm{~h} .26 \mathrm{~min}$. & \\
Participants & & & & \\
& & & & \\
\hline Sub total & Inter-group & 9 & 7h.48min. & \\
\hline $\begin{array}{l}\text { 1st Gen. D-T } \\
\text { Bilin. }\end{array}$ & One-to-one & $\mathbf{1 2}$ & $\mathbf{1 1 h . 1 4 m i n}$. & 22.163 \\
Participants & & & 2h.48min. & \\
\hline
\end{tabular}




\begin{tabular}{lllll}
\hline & Inter-group & $\mathbf{8}$ & 7h.15min. & \\
\hline Sub total & & $\mathbf{1 1}$ & $\mathbf{1 0 h . 3 m i n .}$ & 21.822 \\
\hline $\begin{array}{l}\text { T monolingual } \\
\text { participants }\end{array}$ & One-to-one & $\mathbf{3}$ & $3 \mathrm{~h} .27 \mathrm{~min}$. & \\
& & & & \\
\hline Sub total & Inter-group & $\mathbf{9}$ & 8h.02min. & \\
\hline In total & & $\mathbf{1 2}$ & $\mathbf{1 1 h . 2 9 m i n .}$ & 23.125 \\
\hline
\end{tabular}

\section{Data Analysis}

All the audio-recordings were transcribed utterance by utterance utilizing a transcription convention software entitled EXMARaLDA (Extensible Markup Language for Discourse Annotation) with utmost accuracy, meaning that the transcripts include indications of pauses, external noises and voices, slips of tongues, hesitation markers, interjections etc. (Schmidt 2005).

Next, in order to determine how temporal -DIK converbial constructions were used by the three groups of participants, two interpreters (the first author of this study and a linguist with a PhD in the field) worked on the data, first individually and then as a rating team. Both interpreters identified the converbs to reveal their frequency of use and evaluated each use of the converb in terms of their morpho-syntactic accuracy and semantic acceptability.

\section{Results of the Study}

The aim of this study is to examine whether there is contact-induced language change in the second-generation bilingual speakers' language regarding the temporal $-D I K$ converbial construction. In the following sections, results regarding the frequency and pattern of use of the temporal -DIK converbial construction are presented.

\section{The Distribution of -DIK Construction in the Corpus}

The frequency of usage of the temporal -DIK converbial construction in secondand first-generation bilingual data, as well as Turkish monolingual data are presented in Table 2. F refers to the frequency of occurrences (tokens) in the data.

Table 2

The frequency of use of temporal converbial-DIK constructions

\begin{tabular}{|c|c|c|c|c|c|c|c|}
\hline \multirow[t]{2}{*}{$\begin{array}{c}\text { Converbial } \\
\text { form }\end{array}$} & \multicolumn{4}{|c|}{ Token Frequency } & \multicolumn{3}{|c|}{$\begin{array}{c}\text { Frequency per hundred } \\
\text { utterance }\end{array}$} \\
\hline & $\begin{array}{l}2^{\text {nd }} \text { Gen } \\
\text { Bilin. }\end{array}$ & $\begin{array}{l}1^{\text {st }} \text { Gen } \\
\text { Bilin. }\end{array}$ & $\begin{array}{c}\text { Monoli } \\
\text { n. }\end{array}$ & $\Sigma$ & $\begin{array}{l}2^{\text {nd }} \mathrm{Gen} \\
\text { Bilin. }\end{array}$ & $\begin{array}{l}1^{\text {st }} \text { Gen } \\
\text { Bilin. }\end{array}$ & $\begin{array}{c}\text { Monoli } \\
\text { n. }\end{array}$ \\
\hline $\begin{array}{c}\text {-DIK } \\
\text { constructio } \\
n s\end{array}$ & 32 & 69 & 151 & 252 & 0,1443 & 0,3161 & 0,6529 \\
\hline
\end{tabular}

The data indicate that the frequency of the usage of the temporal converbial $D I K$ differed between the bilingual and the monolingual participants. Intergenerational analysis reveals that the converbial forms were not as 
prevalent in the second-generation bilingual data (heritage Turkish) as they were in the monolingual and the first-generation bilingual data. The distribution of morphosyntactically complex converbial constructions in the corpus is as follows: 0,1443 percent $(\mathrm{F}=111)$ in the second-generation data, 0,3161 percent $(\mathrm{F}=186)$ in the first-generation data, and 0,6529 percent $(\mathrm{F}=380)$ in the Turkish monolingual data.

In addition to the general distribution, categories of temporal converbial -DIK constructions were examined in the data obtained from the three groups. Table 3 illustrates the distribution of the categories of temporal -DIK converbial constructions.

Table 3

The distribution of temporal -DIK converbial constructions

\begin{tabular}{|c|c|c|c|c|c|c|}
\hline \multirow[t]{2}{*}{ Converbials } & \multicolumn{2}{|c|}{$\begin{array}{l}2^{\text {nd }} \\
\text { Bilinguals }\end{array}$} & \multicolumn{2}{|c|}{$1^{\text {st }}$ Gen. Bilinguals } & \multicolumn{2}{|c|}{$\begin{array}{l}\text { Monolingual } \\
\text { speakers }\end{array}$} \\
\hline & $\mathrm{F}$ & $\%$ & $\mathrm{~F}$ & $\%$ & $\mathrm{~F}$ & $\%$ \\
\hline DIK-Poss.-Case & 9 & 0,0406 & 27 & 0,1237 & 73 & 0,3156 \\
\hline $\begin{array}{l}\text {-DIK-Poss.- } \\
\text { Case Pop }\end{array}$ & 11 & 0,0496 & 23 & 0,1053 & 48 & 0,2075 \\
\hline $\begin{array}{l}\text {-DIK-Poss.- } \\
\text { (Case)- noun- } \\
\text { (Case) }\end{array}$ & 12 & 0,0541 & 19 & 0,0870 & 30 & 0,1297 \\
\hline
\end{tabular}

As presented in Table 3, there appears to be a difference in the frequency of $D I K$ converbial constructions produced by the second generation bilingual participants in total $(F=32)$, the distribution of which corresponds to $0,0406 \%$ $(F=9)$ for -DIK-Poss.-Case (-DIğIndA), 0,0496\% ( F=11) for -DIK-Poss.Case.Pop (DIktAn sonra), and $0,0541 \%(F=12)$ for -DIK-Poss.(Case).Noun: (-DIğI zaman). Poss. (Case). Noun constructions appears to be the most-frequently-used -DIK construction in the second-generation bilingual data. The results also reveal that both the first-generation bilinguals $(0,1237 \% ; F=27)$ and Turkish monolingual speakers $(0,3156 ; F=73)$ make more use of -DIK-Poss.-Case constructions compared to the second-generation bilingual speakers. The statistical analysis of the frequency of use of the temporal converbial category produced by the first and second generation bilinguals and Turkish monolinguals reveals that there is a statistically significant difference between the groups: $(F(56,864)=.000)$. The significance value is 0.000 (i.e., $p=.000$ ), which is below 0.05 . thus, there is a statistically significant difference.

The analysis reveals that the -DIğIndA converbial construction is more frequently used by the participants compared with the other converbial endings constructed with -DIK ending. Figure 1 shows the distribution of frequency of use of temporal converbial construction -DIğIndA in the monolingual, first and second-generation Dutch-Turkish data. 
Figure 1

Temporal -DIğIndA converbial constructions in the three speakers' corpora (per hundred utterances)

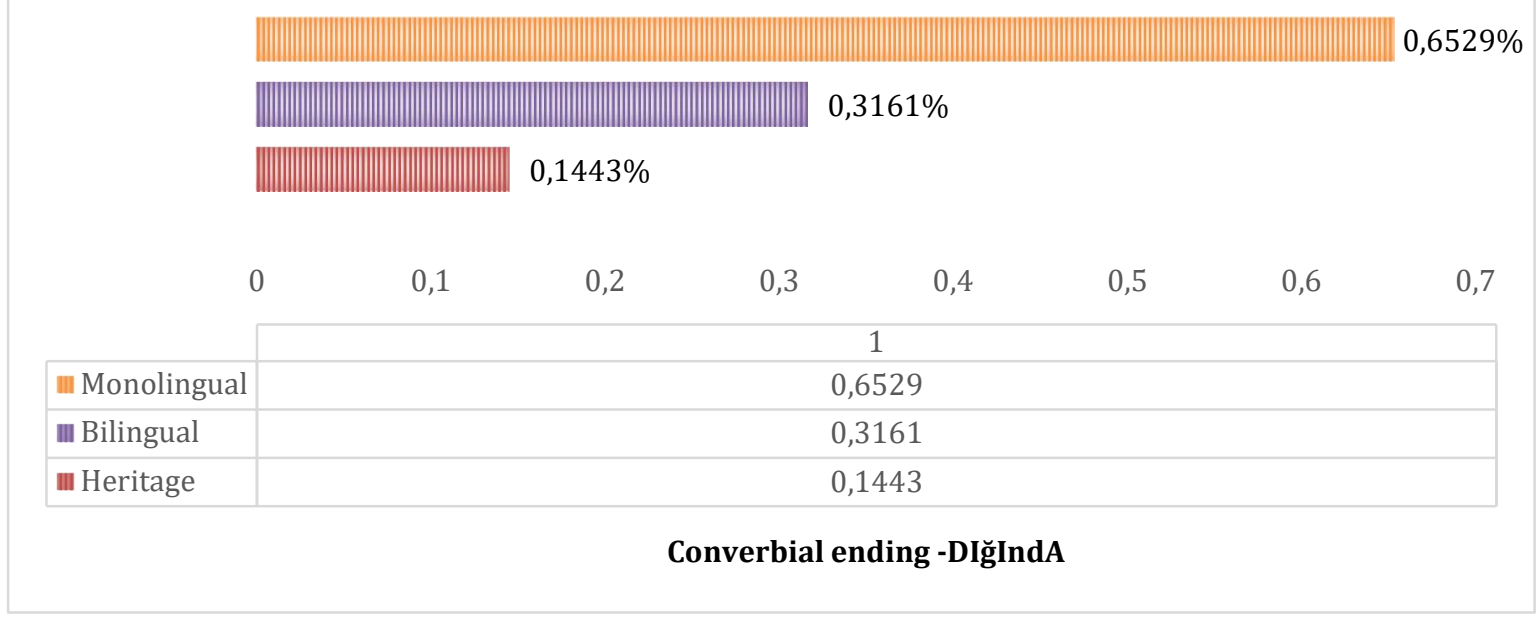

The second phase of the data analyses focuses on the pattern of use of -DIK converbial constructions, i.e., morphosyntactically unconventional and semantically inappropriate use of -DIK constructions in the bilingual data. Thus, the conventional and unconventional usages are analysed by the interpreters. Table 4 presents the frequency of conventional and unconventional use of temporal converbial constructs.

Table 4

The frequency of (un)conventional usages of temporal converbial -DIK constructions

\begin{tabular}{|c|c|c|c|c|c|c|}
\hline \multirow[t]{2}{*}{$\begin{array}{c}\text { Temporal } \\
\text { Converbials }\end{array}$} & \multicolumn{2}{|c|}{$\begin{array}{l}2^{\text {nd }} \\
\text { Bilinguals }\end{array}$} & \multicolumn{2}{|c|}{$1^{\text {st }}$ Gen. Bilinguals } & \multicolumn{2}{|c|}{$\begin{array}{l}\text { Monolingual } \\
\text { speakers }\end{array}$} \\
\hline & $\begin{array}{l}\text { Conv. } \\
\text { (F) }\end{array}$ & $\begin{array}{l}\text { Unconv. } \\
\text { (F) }\end{array}$ & $\begin{array}{l}\text { Conv. } \\
\text { (F) }\end{array}$ & $\begin{array}{l}\text { Unconv. } \\
\text { (F) }\end{array}$ & $\begin{array}{l}\text { Conv. } \\
\text { (F) }\end{array}$ & $\begin{array}{l}\text { Unconv. } \\
\text { (F) }\end{array}$ \\
\hline $\begin{array}{l}- \text {-DIK } \\
\text { constructions }\end{array}$ & 31 & 1 & 69 & 0 & 151 & 0 \\
\hline
\end{tabular}

As shown in Table 4, the interpreters' evaluation of the conventionality of the converbial constructions reveals that all temporal converbial constructs used by Turkish monolingual speakers and first-generation bilingual participants were conventional. The heritage Turkish speaker data contained only one unconventional use of the converbial constructions. In other words, the data reveals that the three groups of participants did not display different patterns of use of the converbial constructions.

In the following parts some samples from the corpus regarding three groups of participants' use of temporal converbial $-D I K$ constructions are presented. Extract 1 presents an instance of $-D I K$ construction in monolingual Turkish data. 
Extract 1

An extract of complex temporal converbial construction -DIK-Poss.-Case in Turkish monolingual data (TMSC)

TM-9 [Girşeher'den Angara'ya çalışmağa gettiğimde] dahaca evli deeldim. TM-9 [TL] Kırşehir-ABL Ankara-DAT work-NOM-DAT go-CONV yet married not-PST1Sg.

TM-9[Eng] When I went to Ankara from Kirşehir for work, I was single.

TM-9 Anamgil habire "evlen, evlen" deyip duruyodu. Bir bayram TM-9[TL] mum-POSS-1PSg. always marry-IMP-2PSg. say-CONV stop-PROG-3PSg a feast

TM-9Eng]My mum always asked me to get married.

TM-9 [Gırşehri'ne döndüğümde] otogarda anamla beni garşılamağa gelmişti. TM-9[TL] Kırşehir-DAT get back-CONV terminal-LOC mum-P0SS-1PSg me meet-NOM-DAT

TM-9[Eng] When I got back to Kirşehir, Arife came to the bus terminal with my mum.

In this extract, a Turkish monolingual speaker tells how he meets his wife when he turns back to his hometown, Kırşehir from Ankara where he works. There is a temporal simultaneity with the actions dönmek (to get back) and karşılamaya gelmek (to go to the terminal to welcome him). In order to create simultaneity and/or overlapping of the representation of actions within an utterance-internal connectivity in discourse, the Turkish monolingual participant utilizes the complex converbial construction -DIK-Poss.-Case in the following utterance [Gırşeher'den Angara'ya çalışmağa gettiğimde] dahaca evli deeldim (When I went to Ankara from Kırşehir for work, I was single). In this utterance, interlocutor constructs a kind of simultaneity relation between the subordinate converbial clause and main clause predicate. In addition to the simultaneity relation, the participant uses this construction to express the temporal parallelism of actions gitmek (to go) and evli olmak (be married).

Extract 2 displays a first-generation bilingual participant's use of temporal converbial -DIK-Poss.-Case construction.

Extract 2

An extract of complex temporal converbial -DIK-Poss.-Case in the first-generation Dutch-Turkish bilingual data (DTBSC)

(12)

DTB-3 [Işıkları gapattığımda] telefon çaldı acı acı o agşam.
DTB-3[TL]light-PL-ACC close-DIK-Poss-Case phone ring-PST-3Sg painfully that evening

DTB-3[Eng]As soon as I turned the lights off, the phone rang, and I got that it was bad news. 
(13)

DTB-3 Gorktum, amma yine de galdırdım telefonu. Abim
DTB-3 [TL] be afraid-PST-1PSg but despite too rise-PST-1PSg phone-ACC
brother-Poss
DTB-3 [Eng] I was scared, but I managed to take it. It was my elder brother.

(14)
DTB-3 gonuşamiyordu.
Adam bi ağlıyo,
anlatamam yaa.
DTB-3 [TL]speak-NEG-ABIL-PrsProg-3PSgman a cry-PrsProg-3PSg explain-
NEG-ABIL PrsProg-3PSg
DTB-3 [Eng] He was crying so heavily that he could not even speak on the phone.

In Extract 2, in connecting the discourse in the utterance, the complex temporal converbial construction in the score area (12) [Işıkları gapattığımda] (As soon as I turned the lights off implies a simultaneity and/or overlapping of the representation of actions in the same utterance, which is compatible with those of the monolingual usages.

When the second-generation bilingual speakers' use of converbial -DIK constructions are explored through subcorpus, a number of unconventional usages can be found. Extract 3 shows an example of an unconventional usage.

Extract 3

An extract complex temporal converbial -DIK-POSS.-Case in the second-generation bilingual data (THSC)

(66)

\begin{tabular}{|l}
\hline THS-7 Voor stage gemeente'ye gittim. Ikze eeh şey dedim ee \\
THS-7 [TL] for internship municipality-DAT go-PST-1Sg I say-PST-1Sg well say- \\
PST-1Sg \\
THS-7 [Eng] I went to the municipality for internship. I said that well after graduation, \\
\hline
\end{tabular}

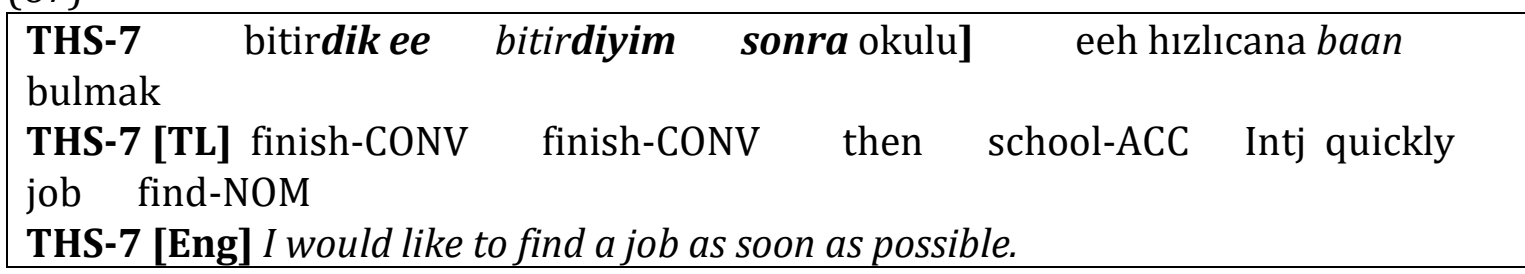

(68)

THS-7 istiyom. Nişanniyım ya. Eflencem. Sordum ee mesela
stage
THS-7 [TL] want-Prog-1Sg engaged-COP-1Sg get married-FUT-1Sg ask-PST-1Sg
instance internship
THS-7 [Eng]I am engaged, I will get married soon. I asked them to suppose that when
I finish my internship here


(69)

THS-7 eeh burada yaptım, dan bitti yani burada devam olur
$\mathrm{mu}$ ?

THS-7 [TL] Intj here do-PST-1Sg then finish-PST-3Sg well here continuation be-Pres Ques Part.

THS-7 [Eng] here is it possible for me to work in the same position.

(70)

THS-7 Officier dedi yoh bitti ya stage, sonra toepassen yapcan
buraya.

THS-7 [TL] official say-PST-3Sg no finish-PST-3Sg internship then apply do-FUT-2Sg here

THS-7 [Eng] Officer told me that after completing my internship, I should apply for it.

In Extract 3, a second-generation bilingual participant talks about his experiences while looking for a suitable internship. During his speech, he codeswitches between Dutch and Turkish to a considerable extent. His speech gives the impression that he has great difficulty in expressing himself fluently, which is signalled by his overuse of interjections (see score areas 66 and 67). Score area 67 encompasses a converbial construction (-DIK.Poss.Case noun:sonra)-and a main clause [ben bitirdik ee bitirdiyim sonra okulu] eeh hizlıcana baan bulmak istiyom (After my graduation, I would like to find a job as soon as possible). First of all, the participant tries to construct a temporal converbial construction with -DIK construction. However, apparently, he tries his best to construct it even though he diverges from the monolingual equivalent as presented in Example 1.

(1) (Ben) okul-u bit-ir-dik-ten sonra hemen iş bul-mak isti-yor-um.

I school-ACC graduate-AOR-CONV-ABL after quickly job find-COMP want-Prog-1PSg

'After graduating from school, I would like to find a job as soon as possible'.

The morphosyntactic structure of the aforementioned -DIK construction has a complex grammatical structure (-DIK.Poss.Case noun:sonra), and he was not able to produce of the ablative case (-DAn). He only used the possessive suffix and forms it as follows: bitirdik ee bitirdiyim sonra (After my graduation), which is a sign of divergence from its monolingual equivalent. THS-7 appears not to be able to analytically decompose these forms and use them in a conventional sense. He has great difficulty in composing the converbial constructions of this highly synthetic construction, and thus fails to employ the case ending.

In the following discourse, the participant seems to avoid using this morphosyntactically complex converbial form (-DIK.Poss.Case noun:sonra). For instance, in score areas (68-69), Sordum ee mesela stage, eeh burada yaptım, dan bitti yani burada devam olur mu? (I asked them to suppose that when I finish my internship here, is it possible for me to work in the same position), the participant uses finite constructions, most likely to avoid forming a non-finite construction. In Turkish, it is also possible to construct a finite clause in such cases. Sordum onlara mesela stajımı burada yaptım, sonra yine burada devam edebilir miyim? (I asked them to suppose that I did my internship here, then is it 
still possible for me to continue working here?) However, after having difficulty in constructing a morphologically complex converbial construction, the participant does not use any equivalent structure. Instead, he prefers to make use of finite constructions with functionally-differentiated Dutch functional words. The Dutch equivalent would be the following: „Ik vroeg hen om te veronderstellen dat ik hier stage liep, is het dan nog steeds mogelijk om hier te blijven werken?" (I asked them to suppose that I did my internship here, then is it still possible for me to continue working here?). Such finite constructions in Turkish speech might be triggered by the Dutch finite structures and the use of conjunctions such as dan "then" and en "and". The Turkish construction including converbial construction could be formed as follows:
(2) [Stajı
bitirdikten
sonra] burada devam edebilir miyim?
internship-ACC complete-AOR-CONV after here continue-ABIL-Int Part
'After completing my internship, could I continue working here?'

Likewise, in score area (70), THS-7 produces a similar construction, involving finite constructions, but this time they are not connected to one another with a Dutch function word. Instead, the semantically equivalent form sonra is utilized Officier dedi yoh bitti ya stage, sonra toepassen yapcan buraya (Officer told me that after completing my internship, I am supposed to apply for the position again). Here, two finite constructions were connected with a function word. However, in monolingual Turkish, it would be more natural to use a converbial construction (-DIK.Poss.Case noun:sonra)-in non-finite construction + main clause as in the following example (3):

(3) [Stajı bitirdikten sonra] başvuru yapacaksın buraya dedi.

internship-ACC complete-AOR-CONV after application do-FUT-2PSg here say-PST-3PSg

'After completing your internship, you are supposed to apply here.'

\section{Discussion and Conclusion}

This study aimed to explore whether the use of temporal converbial -DIK constructions revealed differences in terms of frequency and pattern of use by the first-generation Dutch-Turkish bilingual speakers, second generation DutchTurkish bilingual speakers and the Turkish monolinguals.

The frequency of use plays a significant role in both the model and replica languages during the contact-induced language change processes as suggested by many contact linguists (Johanson 66; Backus 770). In this sense, the frequency of use has a decisive role in accounting for language change. The current study took a closer look at whether there was a difference in the frequency of the temporal -DIK converbial construction across the secondgeneration bilingual Dutch-Turkish speech, the first-generation bilingual DutchTurkish speech, and the Turkish monolingual speech. The findings with respect to the frequency of the converbial construction suggested that the heritage speaker group made significantly less use of the -DIK converbial construction. The results revealed that the frequency of the use of the converbial construction 
by the three participant groups in the study tended to show the following pattern in descending order:

The use of converbial by the monolingual speakers > the first-generation bilingual speakers > the second-generation bilingual speakers

This finding is similar to the findings of Rehbein and Herkenrath (493) and Turan et al. who reported that the German-Turkish bilinguals used converbial constructions less frequently than their monolingual counterparts in the German context (1035). The findings of the present study are also in line with the data presented in Herkenrath's study, which aimed to scrutinize the frequency of the use of the nominalizer -DIK and its divergent forms used by the bilingual informants compared to those of monolinguals (219). The study concluded that the frequency of non-finite $-D I K$ construction and its divergent forms was significantly less in the second-generation informants' speech than in the speech of their monolingual counterparts. The researcher stated that the second-generation speakers living in Germany seem to make less use of the-DIK construction, which showed that the basic syntactic and semantic features of these structures deviated from the control data as a result of language contact.

Our results concerning the decrease in the frequency of use of converbials in the second-generation data also validate the findings presented by Onar Valk, which investigated whether there was a difference in the Dutch-Turkish bilinguals' production of non-finite subordinate clauses as a result of language contact (1 et passim). The researcher reported that the non-finite subordination (including the converbial constructions) was less frequently preferred by the bilingual speakers.

The extent of conventionalization that a linguistic element undergoes in language contact situations has also been examined in this study. Adopting a usage-based framework, the data were analysed for morphosyntactic accuracy and semantic appropriateness of the temporal -DIK constructions. While previous research (Herkenrath 219; Rehbein and Herkenrath 1035; Onar Valk 1 et passim; Turan et al. 1035) reported unconventional use of the converbials they investigated, the data gathered in this study did not reveal any difference between the Turkish monolinguals and the Dutch-Turkish bilinguals' use of the constructions.

The findings of the study allow us to conclude that the temporal $-D I K$ constructions is used less by the Turkish heritage speakers than the firstgeneration Dutch-Turkish and the Turkish monolinguals, which may be considered as a sign of contact-induced change. Yet, the patterns of use of the temporal $-D I K$ constructions by the Turkish heritage speakers are still monolingual-like, which allows us to hypothesize that and the temporal $-D I K$ constructions may not be as vulnerable as the other converbs to contact-induced change. Thus, the question whether the use of temporal -DIK constructions by the Turkish heritage speakers reflect a contact-induced change cannot be answered straightforwardly and further research is needed to clarify on the issue. 


\section{Acknowledgements}

This article is based on the data obtained for the $\mathrm{PhD}$ dissertation "A usage-based investigation of converbial constructions in heritage speakers' Turkish living in the Netherlands" (Akkuş 2019). The study has received no financial support. We would like to thank the anonymous reviewer(s) for their valuable contributions. There is no conflict of interest.

\section{Works Cited}

Akkuş, Mehmet. A usage-based investigation of converbial constructions in heritage speakers' Turkish living in the Netherlands. Unpublished PhD dissertation. Ankara: Middle East Technical University, 2019.

Akoğlu, Gözde, and Yağmur, Kutlay. "First-language skills of bilingual Turkish immigrant children growing up in a Dutch submersion context". International Journal of Bilingual Education and Bilingualism, vol. 19, no. 6, Taylor \& Francis, May 2016, pp. 706-721. https://www.tandfonline.com/, doi.org/10.1080/13670050.2016.1181605

Backus, Ad. Two in One: Bilingual Speech of Turkish Immigrants in the Netherlands. Tilburg: Tilburg University Press, 1996.

Backus, Ad. Turkish as an immigrant language in Europe. In T.K. Bhatia, \& W.C. Ritchie (Eds.), The Handbook of Bilingualism and Multilingualism (2nd Edition). Oxford: Blackwell, 2013, pp. 770-790.

Backus, Ad, and Yağmur, Kutlay. "Differences in Pragmatic Skills between Bilingual Turkish Immigrant Children in the Netherlands and Monolingual Peers". International Journal of Bilingualism, vol. 23, no. 4, SAGE Publications, Aug. 2019, 817-830. https://journals.sagepub.com/, doi.org/10.1177/1367006917703455

Barlow, Michael, and Kemmer, Suzanne. (Eds.). Usage-based Models of Language. Chicago: Chicago University Press, 2000.

Benmamoun, Elabbas, et al. Heritage languages and their speakers: Opportunities and challenges for linguistics. Theoretical Linguistics, 39, 2013, 129-181.

Bybee, Joan. Language, Usage and Cognition. Cambridge University Press, 2010.

Dąbrowska, Ewa. Heritage languages: A new laboratory for empirical linguistics. Theoretical Linguistics, 39(3-4), 2013, 195-201.

Doğruöz, Ayşe Seza, and Backus, Ad. Postverbal elements in immigrant Turkish: Evidence of change? International Journal of Bilingualism, 11, 2007, 185-220.

Doğruöz, Ayșe Seza, \& Backus, Ad. Innovative constructions in Dutch Turkish: An assessment of ongoing contact-induced change. Bilingualism: Language and Cognition, 12(1), 2009, 41-63.

Extra, Guus, et al. Tim Methodological considerations. In G. Extra, \& K. Yağmur (Eds.), Urban Multilingualism in Europe: Immigrant Minority Languages at Home and School (pp. 109-132). Clevedon: Multilingual Matters, 2004.

Haspelmath, Martin. The converb as a cross-linguistically valid category. In M. Haspelmath, \& E. König (Eds.), Converbs in Cross-Linguistic Perspective: Structure and Meaning of Adverbial Verb Forms -Adverbial Participals, Gerunds- (pp. 3-55). Berlin: Mouton de Gruyter.

Haugen, Einar. The Norwegian Language in America: The Bilingual Community. University of Pennsylvania Press, 1953. 
Heine, Bernd. Contact-induced word order change without worder change. In P. Siemund, \& N. Kintana (Eds.), Language Contact and Contact Languages. John Benjamins Publishing Company, 2008.

Heine, Bernd, and Kuteva, Tania. On contact-induced grammaticalization. Studies in Languages, 27(3), 2003, 529-572.

Herkenrath, Annette. The acquisition of -DIK and its communicative range in monolingual versus bilingual constellations. In N. Demir \& A. Menz (eds.), Turcology and Linguistics. Éva Ágnes Csató Festschrift (pp. 219-236). Ankara: Hacettepe University Publications, 2014.

Johanson, Lars. Structural Factors in Turkic Language Contacts. Curzon, 2002.

Kupisch, Tanja. A new term for a better distinction? A view from the higher end of the proficiency scale. Theoretical Linguistics, 39, 2013, 203-214.

Langacker, Ronald W. Concept, Image and Symbol: The Cognitive Basis of Grammar. Mouton de Gruyter, 1991.

Matras, Yaron. Language Contact. Cambridge University Press, 2009.

Matras, Yaron. Contact, convergence, and typology. In R. Hickey (Ed.), The Handbook of Language Contact, (pp. 66-85). Malden, MA: Blackwell Publishing, 2010.

Meir, Natalia, and Polinsky, Maria. Restructuring in heritage grammars: Adjective-noun and numeral-noun expressions in Israeli Russian. Linguistic Approaches to Bilingualism, 11(2), 2021, 222-258.

Meisel, Jürgen M. Heritage language learners: Unprecedented opportunities for the study of grammars and their development? Theoretical Linguistics, 39, 2013, 225 236.

Muysken, Pieter. Challenges of comparability. Theoretical Linguistics, 39, 2013, 237 239.

Myers-Scotton, Carol. Contact Linguistics: Bilingual encounters and grammatical outcomes. Oxford University Press, 2002.

Onar Valk, Pelin. Transformation in Dutch Turkish Subordination? Converging Evidence of Change Regarding Finiteness and Word Order in Complex Clauses. Doctoral Dissertation. Utrecht: LOT, 2015.

Ramstedt, Gustav John. Über die Konjugation des Khalkha-Mongolischen. Otto Zeller, 1903.

Rehbein, Jochen, and Herkenrath, Annette. Converbs in monolinguals' and bilinguals' Turkish. Turkish in Germany - On contact-induced language change of an immigrant language in the multilingual landscape of Europe. In D. Zeyrek, Ç. Sağın Şimşek, U. Ataş, \& J. Rehbein (eds.), Ankara Papers in Turkish and Turkic Linguistics, Turcologica 103, (pp. 493-513.). Wiesbaden: Harrassowitz Verlag, 2015.

Rothman, Jason, and Treffers-Daller, Jeanine. A Prolegomenon to the Construct of the Native Speaker: Heritage Speaker Bilinguals are Natives Too! Applied Linguistics, 35, 2014, 93-98.

Sankoff, David, and Poplack, Shana. A formal grammar for code-switching. Research on Language \& Social Interaction, 14(1), 1981, 3-45.

Siemund, Peter. Language contact: Constraints and common paths of contact-induced language change. In P. Siemund \& N. Kintana (Eds.), Language Contact and Contact Languages (pp. 3-11). John Benjamins Publishing Company, 2008.

Silva-Corvalán, Carmen. The gradual loss of mood distinctions in Los Angeles Spanish. Language Variation and Change, 6(3), 1994, 255-272.

Thomason, Sarah Grey. Language Contact. Edinburgh University Press, 2001. 
Thomason, Sarah Grey, and Kaufman, Terrence. Language Contact, Creolization, and Genetic Linguistics. University of California Press, 1988.

Turan, Dilek, et al. Looking for contact-induced language change: Converbs in heritage Turkish. International Journal of Bilingualism. 24 (5-6), 2020, 1035-1048.

Van Rijswijk, Remy. The strength of a weaker first language - Language production and comprehension by Turkish heritage speakers in the Netherlands. Doctoral Dissertation. Utrecht: LOT, 2016.

Weinreich, Uriel. Languages in Contact: Findings and Problems. The Hague: Mouton 1964 [1953].

Winford, Donald. An Introduction to Contact Linguistics. Blackwell Publishing, 2003. 